\title{
Quantitative Analysis of the Profitability of China's Commercial Banks Based on Factor Analysis
}

\author{
Ying $\mathrm{Wei}^{{ }^{*}}$, Jiaming Zhu ${ }^{2}$, Qingling Liu ${ }^{1}$ \\ ${ }^{1}$ School of Accounting, Anhui University of Finance and Economics, Bengbu 233030, Anhui province, China. E-mail: \\ 3138308209@qq.com \\ ${ }^{2}$ School of Statistics and Applied Mathematics, Anhui University of Finance and Economics, Bengbu 233030, Anhui \\ province, China.
}

Abstract: The profitability of a commercial bank is an important factor to measure its comprehensive development level. Taking the 2019 annual data of China's 16 listed commercial banks as a research sample, the factor analysis method is used to empirically analyze the profitability of each bank, extract four public factors, and calculate the comprehensive score of each bank's profitability. The research results show that the non-performing loan ratio and risk of joint-stock banks are higher, and the capital adequacy ratio is lower. The comprehensive profitability and anti-risk ability of state-owned banks are better than joint-stock banks, and their finances are more stable. This suggests that commercial banks should strengthen their risk control while increasing their profit margins.

Keywords: Commercial Banks; Profitability; Factor Analysis; Principal Component Analysis

\section{Introduction}

As an important part of China's financial system, commercial banks fully play the four major functions of credit intermediary, payment intermediary, economic regulation and financial services, and play a vital role in the stable development of the national economy and the optimal allocation of resources. However, with the continuous advancement of China's interest rate marketization, the risks faced by commercial banks have gradually increased, and the uncertainty of interest rate fluctuations has made competition among commercial banks more intense $\mathrm{e}^{[1]}$. At the same time, a series of factors such as the prosperity and development of the Internet financial industry and the increasingly open financial market are severely impacting the development of traditional physical banking. China's listed banks must have more advanced management systems and efficient asset utilization in order to invincible in the fierce market competition ${ }^{[2]}$. How to accurately measure the profitability of the bank, to achieve the increase of shareholder wealth and the sustainable operation of the bank, is of great significance to the entire financial market. Therefore, based on the factor analysis method, this paper conducts an empirical study on the empirical data of 16 listed state-owned commercial banks and joint-stock commercial banks in China, finds the common factors that affect the profitability of commercial banks, and proposes targeted profitability optimization suggestions to improve China. The purpose of the profitability of commercial banks.

\section{Connotation of profitability}

\footnotetext{
Copyright (C) 2021 Ying Wei et al.

doi: $10.18686 /$ fm.v6i1.3265

This is an open-access article distributed under the terms of the Creative Commons Attribution Non-Commercial License

(http://creativecommons.org/licenses/by-nc/4.0/), which permits unrestricted non-commercial use, distribution, and reproduction in any medium, provided the original work is properly cited.
} 
The profitability of a commercial bank refers to the ability of the bank to make profits in its daily operating activities $^{[3]}$. The stronger the profitability is, the stronger the development ability and competitiveness of the company will be. Compared with general enterprises, commercial banks also have their particularities. For ordinary enterprises, the goal is only to maximize profit and shareholder wealth. As the main financial institution that provides market currency, commercial banks have far higher requirements for asset and risk management and control than other industries. Therefore, in addition to meeting customers' loan requirements, banks must also establish high-quality risk assessment institutions and strict review links.

\section{Literature review}

Foreign scholars have long begun to study the profitability of commercial banks from the perspective of external and internal factors. Smirlock (1984) ${ }^{[4]}$ used the capital market data to evaluate the impact of deposit interest rates on the profitability of commercial banks for the first time using 2,700 US banks as the research object. Since then, academia has begun to further explore the internal factors affecting the profitability of commercial banks. Marijana $(2012)^{[5]}$ conducted a dynamic panel analysis of 16 banks in the Macedonian banking system and believed that among the internal factors of bank profitability, the most important one is operating expense management. Nicolae (2015) ${ }^{[6]}$ assessed the main determinants of bank profitability in the EU-27 during 2004-2011, and pointed out that banks with high liquidity risk, low management efficiency, and high credit risk have poor profitability.

The foreign studies on external macro factors mostly start from the perspective of inflation rate and GDP growth rate. Omar Masood, etc. (2012) ${ }^{[7]}$ based on the data of 25 Islamic banks from 12 countries, and concluded that GDP has a negative impact on the profitability of banks from the asset side, and has a positive impact on the return on equity. For profitable banks, the contribution of inflation is not large. Muhammad (2019) ${ }^{[8]}$ took the Bank of Pakistan as the research object and pointed out that factors such as industry concentration and inflation will all have an impact on the profitability of commercial banks.

Compared with the research of western countries, our country started late, and the early stage mainly used related theories for reference. In recent years, with the successful transformation of the market economy system, competition in the banking industry has become increasingly fierce, and relevant domestic studies have sprung up like mushrooms. Not only did research on profitability from internal and external factors, but also in-depth discussion and practice on how to improve the profitability of commercial banks. The Army (1999) ${ }^{[9]}$ evaluated the impact of the asset-liability structure of China's commercial banks on profitability and believed that the higher the proportion of short-term loans, the higher the risk and the lower their profitability. Su Xin and others. $(2018)^{[10]}$ pointed out that higher taxation will reduce the profitability of commercial banks, while loose monetary policy will increase the lending business of banks and further improve profitability.

In terms of measures to improve bank profitability, Liang Xiaoming (2019)[11] pointed out that commercial banks should scientifically allocate existing resources, reasonably control the income and expenditure of commercial banks' operations, and reduce non-interest costs. Li Lifang $(2020)^{[12]}$ pointed out that under the new situation, cial banks should optimize internal management while paying attention to talent training.

To sum up, the profitability evaluation system of commercial banks is related to many indicators. This article adopts factor analysis method, from the perspective of internal factors that affect profitability, and selects the annual data of 16 listed banks in China for empirical research. Find out the common factors affecting profitability, and put forward relevant suggestions to promote the development of commercial banks in the financial industry.

\section{Construction of the evaluation system}

\subsection{Data source}

Taking into account the completeness of the sample data, this article selects 16 listed commercial banks in China in 2019 as the research object. The sample covers two types of listed banks in China: state-owned commercial banks and 
joint-stock commercial banks are extremely representative and comparable. The data comes from the annual report of China's commercial banks published by www.cninfo.com.cn.

\subsection{Composition of the evaluation system}

For the selection of relevant variables, refer to the research perspectives of scholars such as Ni Jing (2019) ${ }^{[13]}$ and He Jiahuan (2020) ${ }^{[14]}$ and their own characteristics, and select the return on net assets according to the principles of importance, comprehensiveness and feasibility (ROE), cost-to-income ratio (CBB) and other eleven variables are used to construct the evaluation system of commercial banks' profitability. The definition and calculation formula of specific variables are shown in Table 1. It is worth noting that the unit of basic earnings per share is yuan/share, and all other data are in millions. Considering that there are both absolute numbers and relative numbers in the variables, the data needs to be processed.

Table 1. Definition and calculation formula of variables

\begin{tabular}{|l|l|l|}
\hline Variable & Definition & Calculation formula \\
\hline Return on net assets & $\mathrm{X}_{1}$ & Net profit divided by owner's equity \\
\hline Return on total assets & $\mathrm{X}_{2}$ & Net profit divided by total assets \\
\hline Net interest yield & $\mathrm{X}_{3}$ & Net interest income divided by interest-earning assets \\
\hline Non-performing loan ratio & $\mathrm{X}_{4}$ & Non-performing loan balance divided by total asset balance \\
\hline Cost-to-income ratio & $\mathrm{X}_{5}$ & Total cost divided by total revenue \\
\hline Equity to assets ratio & $\mathrm{X}_{6}$ & Owners' equity divided by total assets \\
\hline Basic earnings per share & $\mathrm{X}_{7}$ & $\begin{array}{l}\text { Current net profit divided by weighted average number of } \\
\text { ordinary shares }\end{array}$ \\
\hline Provision coverage ratio & $\mathrm{X}_{8}$ & $\begin{array}{l}\text { Balance of current assets divided by balance of current lia- } \\
\text { bilities }\end{array}$ \\
\hline Capital adequacy ratio & $\mathrm{X}_{9}$ & Assets divided by risk assets \\
\hline Net profit & $\mathrm{X}_{10}$ & Total profit minus income tax \\
\hline Interest income & $\mathrm{X}_{11}$ & Total Interest \\
\hline
\end{tabular}

\subsection{Data processing}

In order to eliminate the influence of the dimensionality of the original data and enhance the comparability between the data, we carry out the Z-score standardization process on the selected data. This process is easier to carry out through the SPSS software. The formula is as follows:

$X_{\mathrm{i}}{ }^{*}=\frac{X_{\mathrm{i}}-E\left(X_{\mathrm{i}}\right)}{\sqrt{D\left(X_{i}\right)}}$

Among them: $\mathrm{E}\left(\mathrm{X}_{\mathrm{i}}\right)$ is the sample mean, $\mathrm{D}\left(\mathrm{X}_{\mathrm{i}}\right)$ is the sample variance.

The analysis of the profitability of China's commercial banks is all based on factor analysis.

\section{Research ideas}

First, in order to verify the applicability of the factor analysis method, we perform the sphericity test and the calculation of the common factor variance on the selected sample data. If the test is passed and the factor analysis method is applicable, then continue to extract the common factors, name and correct the common factors hand over the rotation process, and finally determine the comprehensive score of each commercial bank according to the weight and draw a conclusion.

\subsection{Data verification}


After standardizing the data, in order to verify whether this problem is applicable to factor analysis, we use SPSS21.0 to perform KMO and Bartlett tests on the data. The results are shown in Table 2. The KMO test result is 0.557 greater than 0.5 , and the Sig value is 0.000 , which is significantly less than the given significance level, which meets the requirements of factor analysis, so the data can be factored.

Table 2. KMO and Bartlett's test

\begin{tabular}{|l|l|l|}
\hline \multicolumn{2}{|l|}{ Kaiser-Meyer-Olkin measure of sampling adequacy } & 0.557 \\
\hline \multirow{3}{*}{ Bartlett's sphericity test } & Approximate chi-square & 172.475 \\
\cline { 2 - 3 } & df & 55 \\
\cline { 2 - 3 } & Sig. & 0.000 \\
\hline
\end{tabular}

\subsection{Common factor variance}

Table 3 shows the frequency of factor analysis. From the extracted feature root common degree, it can be seen that the common degree of each variable is higher than 0.8 , indicating that the variable loses less information, and more information can be obtained from it, which is further verified Applicability of factor analysis.

Table 3. Common factor variance

\begin{tabular}{|l|l|l|l|l|l|l|l|l|l|l|l|}
\hline Factor & $\mathbf{X}_{\mathbf{1}}$ & $\mathbf{X}_{\mathbf{2}}$ & $\mathbf{X}_{\mathbf{3}}$ & $\mathbf{X}_{\mathbf{4}}$ & $\mathbf{X}_{\mathbf{5}}$ & $\mathbf{X}_{\mathbf{6}}$ & $\mathbf{X}_{\mathbf{7}}$ & $\mathbf{X}_{\mathbf{8}}$ & $\mathbf{X}_{\mathbf{9}}$ & $\mathbf{X}_{\mathbf{1 0}}$ & $\mathbf{X}_{\mathbf{1 1}}$ \\
\hline Initial & 1 & 1 & 1 & 1 & 1 & 1 & 1 & 1 & 1 & 1 & 1 \\
\hline Extract & 0.844 & 0.979 & 0.838 & 0.930 & 0.819 & 0.809 & 0.902 & 0.958 & 0.804 & 0.956 & 0.923 \\
\hline
\end{tabular}

\subsection{Common factor selection}

We continue to use SPSS 21.0 to analyze the data, and obtain the eigenvalues of each factor and the variance contribution rate as shown in Table 4. Combining with the gravel chart in Figure 1, it can be seen that the eigenvalues of the first four items are $3.908,3.679,1.130$, and 1.044, which are all greater than 1, and the cumulative variance contribution rate is $88.734 \%$, indicating that the first four factors have a significant degree of explanation to the whole. And it contains the main information of the original variable, so the first four factors should be extracted as the main components and set as $F_{1}, F_{2}, F_{3}$, and $F_{4}$ respectively. In order to make the relationship between factors more obvious, we perform rotation processing. After factor rotation, the eigenvalues of the first four factors become more significant, so we will extract the first four factors as common factors.

Table 4. Total variance explained

\begin{tabular}{|c|c|c|c|c|c|c|}
\hline \multirow{2}{*}{ Ingredient } & \multicolumn{3}{|c|}{ Initial Eigenvalue } & \multicolumn{3}{|c|}{ Extract The Sum Of Squares And Load } \\
\hline & Total & Variance(\%) & Cumulative(\%) & Total & Variance $(\%)$ & Cumulative(\%) \\
\hline 1 & 3.908 & 35.528 & 35.528 & 3.908 & 35.528 & 35.528 \\
\hline 2 & 3.679 & 33.443 & 68.970 & 3.679 & 33.443 & 68.970 \\
\hline 3 & 1.130 & 10.268 & 79.239 & 1.130 & 10.268 & 79.239 \\
\hline 4 & 1.044 & 9.495 & 88.734 & 1.044 & 9.495 & 88.734 \\
\hline 5 & 0.557 & 5.065 & 93.798 & - & - & - \\
\hline 6 & 0.342 & 3.105 & 96.903 & - & - & - \\
\hline 7 & 0.226 & 2.055 & 98.957 & E & - & - \\
\hline 8 & 0.079 & 0.717 & 99.675 & - & - & - \\
\hline 9 & 0.020 & 0.179 & 99.853 & - & - & E \\
\hline 10 & 0.015 & 0.140 & 99.993 & - & E & E \\
\hline 11 & 0.001 & 0.007 & 100.000 & 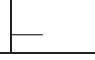 & - & - \\
\hline
\end{tabular}




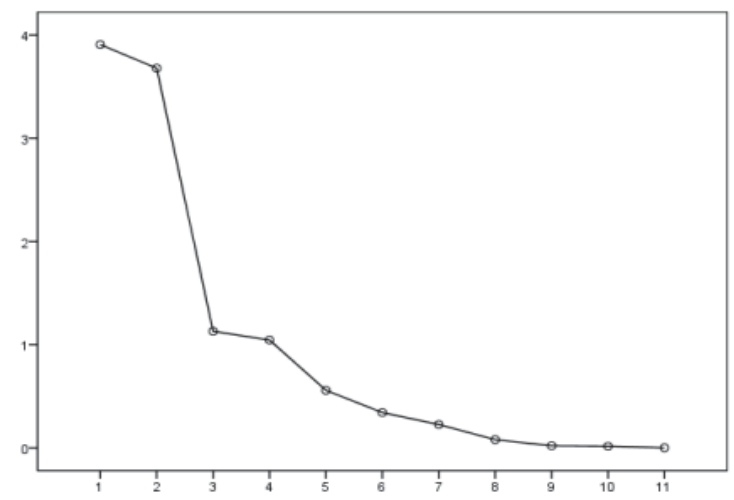

Figure 1. Crushed stone diagram.

\subsection{Factor naming}

Because the variables X2, X4, X6, X7, and X10 in the directly obtained component matrix have large loads on several unrotated factors at the same time, it is difficult to explain, so we use the maximum variance method to orthogonalize the factor loads Rotation processing, as shown in Table 5, is the obtained rotation component matrix. It can be seen that $\mathrm{F}_{1}$ has a larger load on equity-to-asset ratio, capital adequacy ratio, net profit and interest income, which is named the first profitability factor; $\mathrm{F}_{2}$ has a larger load on the non-performing loan ratio and provision coverage ratio, which is called the second profit factor; $\mathrm{F}_{3}$ has a larger load on basic earnings per share, return on equity and return on total assets, and is named as the third profitability factor; $F_{4}$ has a larger load on the net interest rate of return and cost-to-income ratio, and is named the fourth profitability factor.

Table 5. Rotation component matrix

\begin{tabular}{|c|c|c|c|c|}
\hline Ingredient & 1 & 2 & 3 & 4 \\
\hline $\mathrm{X}_{1}$ & 0.067 & 0.585 & 0.704 & -0.036 \\
\hline$X_{2}$ & 0.469 & 0.477 & 0.724 & 0.092 \\
\hline $\mathrm{X}_{3}$ & 0.217 & -0.016 & 0.210 & 0.864 \\
\hline $\mathrm{X}_{4}$ & -0.035 & -0.952 & -0.145 & 0.037 \\
\hline $\mathrm{X}_{5}$ & -0.136 & 0.615 & -0.064 & 0.646 \\
\hline $\mathrm{X}_{6}$ & 0.839 & -0.245 & 0.112 & 0.180 \\
\hline $\mathrm{X}_{7}$ & -0.302 & 0.074 & 0.872 & 0.210 \\
\hline $\mathrm{X}_{8}$ & -0.107 & 0.867 & 0.402 & 0.182 \\
\hline $\mathrm{X}_{9}$ & 0.880 & 0.147 & 0.050 & 0.071 \\
\hline $\mathrm{X}_{10}$ & 0.973 & 0.002 & -0.084 & -0.041 \\
\hline $\mathrm{X}_{11}$ & 0.950 & -0.015 & -0.140 & 0.014 \\
\hline
\end{tabular}

* Extraction method: principal component; rotation method: orthogonal rotation method with Kaiser normalization; a. The rotation converges after 11 iterations.

\subsection{Factor score}

According to the component score coefficient matrix in Table 6, we can calculate the scores of each factor and the comprehensive score of profitability. We use the weighted method to calculate the comprehensive score of the factors, that is, according to the explanation degree of variance contribution rate of the three common factors and accumulate them according to the three factors. The proportion of the variance contribution rate is used as the weight. The specific calculation process is as follows: 
Table 6. Component score coefficient matrix

\begin{tabular}{|l|l|l|l|l|}
\hline Ingredient & $\mathbf{1}$ & $\mathbf{2}$ & $\mathbf{3}$ & $\mathbf{4}$ \\
\hline $\mathrm{X}_{1}$ & 0.025 & 0.104 & 0.320 & -0.187 \\
\hline $\mathrm{X}_{2}$ & 0.126 & 0.032 & 0.349 & -0.089 \\
\hline $\mathrm{X}_{3}$ & 0.011 & -0.160 & 0.040 & 0.716 \\
\hline $\mathrm{X}_{4}$ & -0.022 & -0.465 & 0.179 & 0.153 \\
\hline $\mathrm{X}_{5}$ & -0.065 & 0.275 & -0.311 & 0.514 \\
\hline $\mathrm{X}_{6}$ & 0.216 & -0.173 & 0.126 & 0.123 \\
\hline $\mathrm{X}_{7}$ & -0.095 & -0.247 & 0.560 & 0.080 \\
\hline $\mathrm{X}_{8}$ & -0.031 & 0.318 & -0.001 & 0.021 \\
\hline $\mathrm{X}_{9}$ & 0.237 & 0.065 & -0.021 & -0.008 \\
\hline $\mathrm{X}_{10}$ & 0.267 & 0.041 & -0.057 & -0.078 \\
\hline $\mathrm{X}_{11}$ & 0.258 & 0.043 & -0.098 & -0.020 \\
\hline
\end{tabular}

$\mathrm{F}_{1}=0.025 \mathrm{X}_{1}+0.126 \mathrm{X}_{2}+0.011 \mathrm{X}_{3}-0.022 \mathrm{X}_{4}-0.065 \mathrm{X}_{5}+0.216 \mathrm{X}_{6}-0.095 \mathrm{X}_{7}-0.031 \mathrm{X}_{8}+0.237 \mathrm{X}_{9}+0.267 \mathrm{X}_{10}+0.258 \mathrm{X}_{11}$ $\mathrm{F}_{2}=0.104 \mathrm{X}_{1}+0.032 \mathrm{X}_{2}-0.160 \mathrm{X}_{3}-0.465 \mathrm{X}_{4}+0.275 \mathrm{X}_{5}-0.173 \mathrm{X}_{6}-0.247 \mathrm{X}_{7}+0.318 \mathrm{X}_{8}+0.065 \mathrm{X}_{9}+0.041 \mathrm{X}_{10}+0.043 \mathrm{X}_{11}$ $\mathrm{F}_{3}=0.320 \mathrm{X}_{1}+0.349 \mathrm{X}_{2}+0.040 \mathrm{X}_{3}+0.179 \mathrm{X}_{4}-0.311 \mathrm{X}_{5}+0.126 \mathrm{X}_{6}+0.560 \mathrm{X}_{7}-0.001 \mathrm{X}_{8}-0.021 \mathrm{X}_{9}-0.057 \mathrm{X}_{10}-0.098 \mathrm{X}_{11}$ $\mathrm{F}_{4}=-0.187 \mathrm{X}_{1}-0.089 \mathrm{X}_{2}+0.716 \mathrm{X}_{3}+0.153 \mathrm{X}_{4}+0.514 \mathrm{X}_{5}+0.123 \mathrm{X}_{6}+0.080 \mathrm{X}_{7}+0.021 \mathrm{X}_{8}-0.008 \mathrm{X}_{9}-0.078 \mathrm{X}_{10}-0.020 \mathrm{X}_{11}$ $\mathrm{F}=\left(35.528 \mathrm{~F}_{1}+33.443 \mathrm{~F}_{2}+10.268 \mathrm{~F}_{3}+9.495 \mathrm{~F}_{4}\right) / 88.734$

* Extraction method: principal component; rotation method: orthogonal rotation method with Kaiser standardization.

\subsection{Analysis of comprehensive score results}

Table 7. Comprehensive scores and rankings of each bank's profitability

\begin{tabular}{|l|l|l|l|l|l|l|}
\hline Commercial bank name & F1 & F2 & F3 & F4 & F & Rank \\
\hline China Construction Bank & 1.8619 & -0.0581 & -0.1797 & 0.0565 & 0.7088 \\
\hline Industrial and Commercial Bank of China & 2.0709 & -0.1947 & -0.3165 & -0.1190 & 0.7064 & 2 \\
\hline China Merchants Bank & -0.0680 & 0.5783 & 1.2602 & 1.6957 & 0.5180 & 3 \\
\hline Agricultural Bank of China & 0.6871 & 0.7761 & -0.9489 & 0.2998 & 0.4899 & 4 \\
\hline Bank of Ningbo & -1.1228 & 2.0284 & -0.6706 & 1.1282 & 0.3581 & 5 \\
\hline Bank of China & 0.9356 & 0.3047 & -0.8393 & -0.4394 & 0.3453 & 6 \\
\hline Bank of Nanjing & -1.3383 & 1.7769 & -0.5768 & -1.2510 & -0.0667 & 7 \\
\hline Bank of Communications of China & 0.0233 & 0.2148 & -0.8281 & -0.6603 & -0.0762 & 8 \\
\hline China Everbright Bank & -0.1923 & -0.5691 & -0.3970 & 0.6630 & -0.2665 & 9 \\
\hline Ping An Bank & -0.4314 & -0.8772 & -0.0653 & 1.9214 & -0.3053 & 10 \\
\hline China CITIC Bank & -0.4260 & -0.4208 & 0.0911 & 0.0142 & -0.3171 & 11 \\
\hline Hua Xia Bank & -0.6741 & -0.4834 & 0.0651 & 0.8159 & -0.3573 & 12 \\
\hline Bank of Beijing & -0.3663 & -0.2474 & -0.0927 & -1.0428 & -0.3622 & 13 \\
\hline Minsheng Bank & -0.2994 & -0.4060 & -0.0244 & -1.0011 & -0.3828 & 14 \\
\hline Industrial Bank & -0.5426 & -0.6058 & 1.4472 & -1.2795 & -0.4150 & 15 \\
\hline Shanghai Pudong Development Bank & -0.1175 & -1.8166 & 2.0758 & -0.8016 & -0.5773 & 16 \\
\hline
\end{tabular}


Substituting the data into the calculation formula, the results are shown in Table 7. Judging from the comprehensive profit scores of commercial banks, it is obvious that the profitability of state-owned banks is higher than that of joint-stock banks. The five state-owned banks selected in this article are Industrial and Commercial Bank of China, China Construction Bank, Agricultural Bank of China, Bank of China, and Bank of Communications. The profitability rankings of Bank of Communications are one, two, four, six and eight respectively, but the profitability of China Bank of Communications is negative, which is weaker than other state-owned banks. Among the joint-stock banks, China Merchants Bank has the strongest profitability, followed by Bank of Ningbo, while other joint-stock banks have negative profitability, and Shanghai Pudong Development Bank has the lowest profitability, which is at a low level, indicating that measures need to be taken to strengthen profitability.

Judging from the scores of all bank in the four profit factors, the scores of state-owned banks in the first profitability factor $F_{1}$ are all greater than zero, and the $F_{1}$ scores of other joint-stock banks are all negative, indicating that state-owned banks have higher interest income, The proportion of risky assets is relatively low. Second, Shanghai Pudong Development Bank's second profitability factor $F_{2}$ ranks the lowest among all banks, resulting in the lowest score for its comprehensive profitability, indicating that it has a high non-performing loan ratio and a low provision coverage ratio, and its ability to withstand external risks need to be improved. Shanghai Pudong Development Bank should pay more attention to the credit status of credit customers, and appropriately increase the risk loss reserve. Third, the third profitability factor $\mathrm{F}_{3}$ of state-owned banks is generally lower than that of joint-stock banks, indicating that the net income and competitiveness of state-owned banks are low. In general, the fourth profitability factor $F_{4}$ of joint-stock banks is lower than that of state-owned banks, and $\mathrm{F}_{4}$ is directly proportional to income and net interest income, indicating that joint-stock banks have relatively low net interest income and their income comes from other businesses. In addition, compared with state-owned banks, the main source of income of joint-stock banks are not only interest income, but also other intermediate businesses that make their income higher. In short, the advantages of state-owned banks and joint-stock banks are strong ability to withstand risks and financial stability, while joint-stock banks pay more attention to the increase of profits, and ignoring the control of risks.

\section{Conclusions and recommendations}

In this paper, the profitability of 16 commercial banks in China is studied by factor analysis. The analysis results show that interest income is still the main income source of state-owned banks, while other business income accounts for a relatively large proportion of the income sources of joint-stock banks. At the same time, the ratio and risk of non-performing loans of joint-stock banks are relatively high. Compared with joint-stock banks, state-owned banks have stronger anti-risk ability, fewer risky assets, and higher capital adequacy ratios. In order to improve profitability, banks should reduce operating costs, improve the construction of risk management mechanisms, increase the profitability of interest-bearing assets, vigorously develop intermediary businesses, and better respond to the bank's transformation. The specific proposals are as follows.

\subsection{Control costs and reduce cost-to-income ratio}

The lower the cost-to-income ratio is, the stronger the profitability will be. For commercial banks, reducing operating costs and expenditures is an important means to improve profitability. The operating costs of China's commercial banks are mainly divided into interest costs and non-interest costs. Interest cost is mainly determined by market interest rates, so it is not easy to adjust. Non-interest costs is the management costs in the process of bank's business operations, such as advertising fees and rent, salary, etc., can be effectively lowered by some means. Banks should minimize loan losses, reduce non-interest cost, improve the use efficiency of disposable funds, and control the income and expenditures of commercial banks. Only in this way can the commercial banks' operating profits be sustained.

\subsection{Innovate income channels and broaden business scope}

With the intensification of financial market competition, banks have narrower space for increasing interest income. 
It is difficult to maintain the state of relying solely on deposits and loan spreads to generate major revenue. To realize the sustainable operation and development of China's commercial banks, it is necessary to encourage innovative business development and increase the scale of assets while ensuring the stable development of the loan business. First of all, interest income as the first profit factor directly affects the banks' profit. Banks should continue to develop loan business and develop it into main business revenue. At the same time, it should combine its own conditions and China's macro monetary policy to determine reasonable and appropriate. During the development process, we will continue to handle the dynamic and balanced development of scale and benefits. At the same time, commercial banks should actively develop intermediary businesses and expand business scope. Intermediary business refers to the business in which the bank only handles various entrusted matters for customers as a medium. This way of obtaining income without providing assets broadens the bank's channels for increasing sources of profit and greatly reduces risks. Second, it should give full play to its advantages in information, personnel, and localized financial services, and gradually expand the market share of low-risk intermediate businesses such as leasing, agency, entrustment, information consulting, and customer wealth management, so as to provide society with more high-quality and comprehensive financial services.

\subsection{Strengthen the prevention of credit risks and appropriately increase the loss reserve}

While pursuing profits, banks often neglect the investigation of credit customer risks, which leads to a relatively large proportion of risky assets and more bad debt losses in commercial banks. Commercial banks should establish a complete risk control systems to increase their capital adequacy ratio. Carry out strict and scientific due diligence in the credit link, fully review the credit use link, establish a supervision system in the review link, pay close attention to the loan follow-up, ensure the effectiveness and adequacy of guarantees, and reduce credit risks. At the same time, banks should make reasonable estimates of asset losses and bad debt reserves based on prudent accounting principles, make provision for impairment of possible asset losses, and appropriately increase reserves to deal with risks, improve their ability to withstand risks, and ensure the bank's operations continue to develop continuously.

\subsection{Improve risk response capabilities and strengthen internal control}

Due to the particularity of the year, the epidemic has a great impact on China's economic development. Especially for banks, the epidemic has increased credit risk, directly impacted the real economy, and may induce other joint financial risks. Therefore, it is urgent to reverse the downward trend in economic growth and improve the ability to cope with risk. Firstly, banks should establish effective risk identification, risk monitoring, and risk control procedures to improve risk management. Secondly, we should strengthen credit management, strictly control the occurrence of credit risk, liquidity risk and market risk, continuously optimize our own credit structure, improve our ability to cope with risk, and actively respond to changes in the external environment and macroeconomic policies. At the same time, it is necessary to strengthen the internal management and the continuous optimization of internal personnel to maintain the stability and safety of the internal structure. It is also necessary to reform the existing business structure of commercial banks, improve the overall organization and management ability in an all-round way,, and ultimately form a business model that can efficiently create high profits and improve the profitability of banks.

\section{References}

1. Cai L. An empirical study on the influencing factors of profitability of city commercial banks (in Chinese). Zhejiang University 2019.

2. Li J. Research on the profitability evaluation system of China's listed commercial banks based on the perspective of EVA (in Chinese). Ocean University of China 2013.

3. Hou Y. Theoretical and empirical research on the factors influencing the profitability of Chinese commercial banks (in Chinese). Shanxi University of Finance and Economics 2016.

4. Michael C. An analysis of bank risk and deposit rate ceilings: evidence from the capital markets. Smirlock Michael 1984; 13(2).

5. Curak M, Poposki K, Pepur S. Profitability determinants of the macedonian banking sector in changing environ- 
ment. Procedia-Social and Behavioral Sciences 2012; 44.

6. Petria N, Capraru B, Ihnatov I. Determinants of banks' profitability: evidence from EU 27 banking systems. Procedia Economics and Finance 2015; 20.

7. Masood O, Ashraf M. Bank-specific and macroeconomic profitability determinants of Islamic banks. Qualitative Research in Financial Markets 2012; 4(2/3).

8. Haris M. Profitability determinants of banks in emerging economies: the case of Pakistan. Jiangsu University 2019.

9. Lu J, Wei Y. Analysis of the profitability and asset-liability structure of China's commercial banks (in Chinese). Journal of Financial Research 1999; (11): 3 - 5.

10. Su X, Liu B. Research on the profitability and influencing factors of China's commercial banks (in Chinese). China Collective Economy 2018; (04): 85 - 86.

11. Liang X, Nong J. Analysis of the influencing factors of the profitability of China's commercial banks under the new normal of the economy (in Chinese). Accounting Study 2019; (32): 162+164.

12. Li L. Analysis of commercial banks' increased profitability in the new situation (in Chinese). National Circulation Economy 2020; (6): 176 - 177.

13. Ni J. Research on the influencing factors and countermeasures of the profitability of China's city cial banks (in Chinese). Science and Technology Entrepreneurship Monthly 2019; 32(02): 49 - 52.

14. He J. An empirical analysis of commercial bank profitability based on factor analysis (in Chinese). Modern Business 2020; (26): 131 - 132. 